Article

\title{
Effect of Meiotic Polyploidisation on Selected Morphological and Anatomical Traits in Interspecific Hybrids of Brassica oleracea $\times$ B. napus
}

\author{
Agnieszka Marasek-Ciolakowska ${ }^{1, * \mathbb{D}}$, Piotr Kamiński ${ }^{2, * \mathbb{D}}$, Małgorzata Podwyszyńska ${ }^{1}$ (D), Urszula Kowalska ${ }^{1}$, \\ Michał Starzycki ${ }^{3}$ (D) and Elżbieta Starzycka-Korbas ${ }^{3}$ (D)
}

1 Department of Applied Biology, The National Institute of Horticultural Research, Konstytucji 3 Maja 1/3 Str., 96-100 Skierniewice, Poland; malgorzata.podwyszynska@inhort.pl (M.P.); urszula.kowalska@inhort.pl (U.K.)

2 Department of Genetics and Breeding, The National Institute of Horticultural Research, Konstytucji 3 Maja 1/3 Str., 96-100 Skierniewice, Poland

3 Department of Genetics and Breeding of Oilseed Plants, Division of Poznań, Plant Breeding and Acclimatization National Research Institute, Strzeszyńska 36 Str., 60-479 Poznan, Poland; m.starzycki@ihar.edu.pl (M.S.); e.starzycka-korbas@ihar.edu.pl (E.S.-K.)

* Correspondence: agnieszka.marasek@inhort.pl (A.M.-C.); piotr.kaminski@inhort.pl (P.K.)

\section{check for} updates

Citation: Marasek-Ciolakowska, A.; Kamiński, P.; Podwyszyńska, M.;

Kowalska, U.; Starzycki, M.; Starzycka-Korbas, E. Effect of Meiotic Polyploidisation on Selected Morphological and Anatomical Traits in Interspecific Hybrids of Brassica oleracea $\times$ B. napus. Agronomy 2022, 12, 26. https://doi.org/10.3390/ agronomy12010026

Academic Editor: Pasquale Tripodi

Received: 29 November 2021

Accepted: 20 December 2021

Published: 23 December 2021

Publisher's Note: MDPI stays neutral with regard to jurisdictional claims in published maps and institutional affiliations.

Copyright: (C) 2021 by the authors. Licensee MDPI, Basel, Switzerland. This article is an open access article distributed under the terms and conditions of the Creative Commons Attribution (CC BY) license (https:// creativecommons.org/licenses/by/ $4.0 /)$.

\begin{abstract}
In Brassica, interspecific hybridisation plays an important role in the formation of allopolyploid cultivars. In this study, the ploidy of $F_{1}$ and $F_{2}$ generations resulting from interspecific hybridisation between $B$. oleracea inbred lines of head cabbage (B. oleracea $\mathrm{L}$. var. capitata) $(2 \mathrm{n}=18)$ and kale (B. oleracea L. var. acephala) $(2 \mathrm{n}=18)$ with inbred lines of rapeseed (B. napus L.) $(2 \mathrm{n}=38)$ was examined by flow cytometry analysis and chromosome observation. Furthermore, the effect of meiotic polyploidisation on selected phenotypic and anatomical traits was assessed. The $\mathrm{F}_{1}$ hybrids of head cabbage $\times$ rapeseed (S3) and kale $\times$ rapeseed crosses (S20) were allotriploids with $2 n=28$ chromosomes, and nuclear DNA amounts of 1.97 (S3) and $1.99 \mathrm{pg}$ (S20). These values were intermediate between $B$. oleracea and $B$. napus. In interspecific hybrids of the $F_{2}$ generation, which were derived after self-pollination of $F_{1}$ hybrids (FS3, FS20) or by open crosses between $F_{1}$ generation hybrids (FC320, FC230), the chromosome numbers were similar $2 n=56$ or $2 n=55$, whereas the genome sizes varied between 3.81 (FS20) and 3.95 pg 2C (FC230). Allohexaploid $F_{2}$ hybrids had many superior agronomic traits compared to parental $B$. napus and B. oleracea lines and triploid $F_{1}$ hybrids. In the generative stage, they were characterised by larger flowers and flower elements, such as anthers and lateral nectaries. $\mathrm{F}_{2}$ hybrids were male and female fertile. The pollen viability of $\mathrm{F}_{2}$ hybrids was comparable to parental genotypes and varied from $75.38 \%$ (FS3) to $88.24 \%$ (FC320), whereas in triploids of $\mathrm{F}_{1}$ hybrids only $6.76 \%$ (S3) and $13.46 \%$ (S20) of pollen grains were fertile. Interspecific hybrids of the $\mathrm{F}_{2}$ generation derived by open crosses between plants of the $\mathrm{F}_{1}$ generation (FC320, FC230) had a better ability to set seed than $F_{2}$ hybrids generated from the self-pollination of $\mathrm{F}_{1}$ hybrids. In the vegetative stage, $\mathrm{F}_{2}$ plants had bigger and thicker leaves, larger stomata, and significantly thicker layers of palisade and spongy mesophyll than triploids of the $\mathrm{F}_{1}$ generation and parental lines of B. oleracea and B. napus. The allohexaploid $F_{2}$ hybrids analysed in this study can be used as innovative germplasm resources for further breeding new vegetable Brassica crops at the hexaploid level.
\end{abstract}

Keywords: $B$. oleracea $\times$ B. napus; anatomy; flow cytometry; interspecific crosses; phenotype evaluation; polyploidy breeding; phenotypic variation

\section{Introduction}

Interspecific hybridisation plays an important role in the origins of polyploid cultivars, and it is acknowledged as the main source of genetic variation in cultivated plants. Approximately $70 \%$ of angiosperms have undergone polyploidisation, including whole genome duplication (WGD), during species development [1,2]. Polyploidy may result 
from the functioning of $2 n$ gametes (meiotic doubling), distant hybridisation followed by chromosome doubling, or induced through artificial chromosome doubling (mitotic polyploidisation) [3,4]. The rate of $2 n$ gamete production in plants is low. Most of the species of Brassicacea produce less than $2 \%$ of $2 n$ male gametes, whereas a small number has more than 5\% (up to 85\%) production [5]. According to Ramsey and Schemske [6], distant hybridisation increase the frequency of unreduced gamete production. Meiotic polyploidisation via crossing with $2 n$ gamete producing genotypes is one of the main methods currently used to obtain polyploidy tulip [4]. Similarly, in Lilium many triploid hybrids have resulted from the use of unreduced gametes [4]. Polyploid plants originating from the process of meiotic polyploidisation are superior to those produced from somatic doubling due to enhanced meiotic recombination, which leads to the rapid creation of genetic diversity [7]. Polyploidisation usually has a positive effect on growth habits, enhanced vigour, the size of generative and vegetative organs, and yield [8]. Good examples are triploid cultivars of apples, most of which are characterised by immunity to scab and high fruit marketable quality [9]. Similarly, allohexaploid wheat has a higher yield potential and is more vigorous than its diploid and tetraploid progenitors [10]. Allopolyploid crops that contain two or more genomes derived from distant species usually benefit from combining their traits and exhibit improved agronomic characteristics, better generative reproduction, and are useful as material for the breeding of new polyploid crop species [11].

Brassica is the most distinguished genus in the family Brassicaceae, which includes agriculturally important food crops domesticated for edible oil, vegetables, spices, forage crops, and ornamental plants $[12,13]$. Their genomes show high flexibility with respect to the ploidy modification, which allows them to easily adapt to various environmental conditions. The allotetraploid species produced by spontaneous interspecific polyploidisation include Brassica juncea (Indian mustard, AABB genome) formed by the hybridisation of diploid B. rapa (turnip rape, AA genome) and B. nigra (black mustard, BB genome), B. carinata (Ethiopian mustard, BBCC genome) formed from B. nigra and B. oleracea (cabbage, kale, CC genome), and B. napus (oilseed rape, rapeseed, swede, AACC genome) [14]. $B$. napus is a more recent allopolyploid species that formed about 7500 years ago by hybridisation between $B$. rapa and B. oleracea [15], which are mainly used as oil vegetables. These allopolyploids are morphologically diverse, including leaf type and shape, wax thickness, position of flowers, inflorescence types, and stack height and thickness [13]. Moreover, they are characterised by several desirable traits. For instance, B. juncea (AABB genome) has non-shattering siliques and disease resistance that are not present in the $A$ or $C$ genomes of B. napus $[16,17]$. B. carinata (BBCC genome) is resistant to diseases that commonly affect other oilseed Brassica spp., such as black rot disease and powdery mildew $[18,19]$, and is resistant to various abiotic stressors, such as salt and heat $[20,21]$. Similarly, allotetraploid $B$. napus gives a higher yield and has increased resistance to biotic and abiotic stress compared to diploid B. rapa [22].

Allopolyploids have been subjected to extensive interspecific hybridisation with diverse parents, and there are examples of the introgression of various desirable characteristics into Brassica crops. For instance, high levels of resistance to black rot disease were found in somatic hybrids between B. oleracea var. botrytis and B. nigra and in all $\mathrm{BC}_{1}$ progeny [23], whereas triploid hybrids $(2 \mathrm{n}=3 \mathrm{x}=\mathrm{ABC})$ produced from the cross $B$. napus (rapeseed, AACC) $\times$ B. nigra (black mustard, BB) and their allohexaploid hybrids (AABBCC) had resistance to blackleg disease inherited from $B$. nigra [24]. Allotetraploid hybrids of the $\mathrm{F}_{2}$ generation between Brassica rapa var. parachinensis (Chinese cabbage) and Brassica oleracea var. italica (broccoli) showed new traits and a high level of nutritional elements [25]. In South Korea, one new leafy vegetable crop was bred from intergeneric the allopolyploid Brassicoraphanus between B. rapa and Raphanus sativus [26].

$B$. oleracea is mainly used as an edible vegetable. The most important $B$. oleracea crops are kale (var. viridis, var. costata, var. medullosa, and var. sabellica), cabbage (var. capitata and var. sabauda), branching bush kale (var. ramosa) cultivated for edible foliage, cauliflower and broccoli (var. botrytis and var. italica) cultivated for their thickened edible 
inflorescences, Brussels sprouts (var. gemmifera) grown for its edible axillary bud leaves, kohlrabi (var. gongyloides) cultivated for its above ground thickened stem, and Chinese kale (var. alboglabra), a leaf vegetable often treated as Brassica alboglabra (Figure 1) [27]. Several genotypes were selected for interspecific crosses. The rapeseed line RAP62, head cabbage IW1234, and kale IW08 inbred lines had valuable agronomical characteristics, including high tolerance to biotic stress, such as resistance to clubroot and Alternaria leaf spot, desired agronomic characteristics, internal uniformity, and high combining ability. We expected that this breeding program could potentially yield new, improved allopolyploid leafy vegetables exhibiting heterosis in respect to their morphology, genome structure, fertility, and improved agronomic characteristics. The neopolyploids could also serve as innovative germplasm resources for further genomic and genetic research. In this study, we aimed to assess the effect of interploidy hybridisation between B. oleracea and B. napus on the ploidy level of the progeny and the variability of selected morphological and anatomical traits in $F_{1}$ and $F_{2}$ generation hybrids.

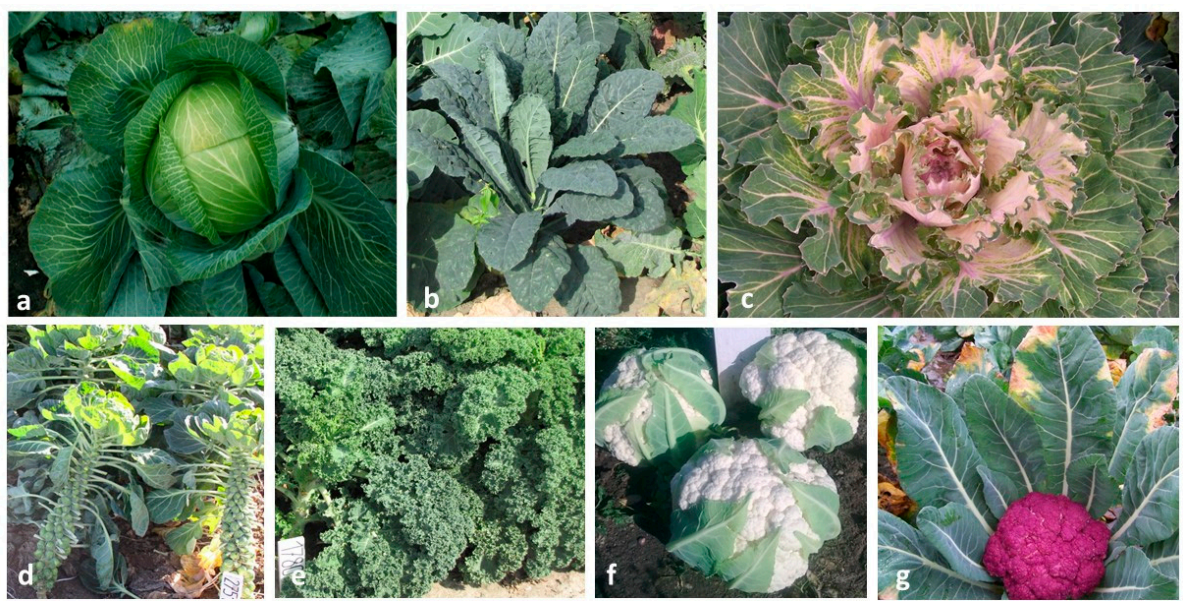

Figure 1. The diversity of Brassica oleracea vegetable crops. (a) Head cabbage (b) Leafy cabbage plants (c) Ornamental leafy cabbage; (d) Brussels sprouts; (e) Kale; (f) Cauliflower; (g) Purple cauliflower.

\section{Materials and Methods}

\subsection{Plant Materials}

The parental genotype of head cabbage IW1234 (B. oleracea L. var. capitata) was developed at the National Institute of Horticultural Research, Department of Genetics and Breeding, Skierniewice, Poland, as a valuable inbred line, which is characterised by a round head shape, good firmness with a 71-77-d vegetation period from planting to harvest, internal uniformity, and good vigour. Kale line (B. oleracea L. var. acephala) IW08 was obtained from the germplasm collection of the National Institute of Horticultural Research. The kale IW08 line had a semi-compact shape with grey-green horizontal, small leaves without petioles with intermediate blistering and crenated edges and was characterised by low susceptibility to clubroot and bacterial diseases in the field. The rapeseed (B. napus) RAP62 line was obtained from the Plant Breeding and Acclimatization National Research Institute, Poznań, Poland. This line had a high seed yield and lower susceptibility to clubroot and Alternaria leaf spot.

Interspecific $\mathrm{F}_{1}$ hybrids (S3, S20) between B. oleracea IW1234 and IW08 and B. napus RAP62 lines were obtained via embryo rescue according to Starzycki et al. [28]. FS3 and FS20 interspecific hybrids of the $F_{2}$ generation were derived after self-pollination of the $F_{1}$ hybrids. Hybrids FC320 and FC230 were obtained by open crosses between plants of the $\mathrm{F}_{1}$ generation. Interspecific hybrids were pollinated following the method described by Kamiński et al. [29,30].

Vernalised plants of parental lines and $F_{1}$ and $F_{2}$ interspecific hybrids were grown in a greenhouse in $5 \mathrm{~L}$ plastic pots filled with Kronen substrate placed on the ground and grown 
at $16-20^{\circ} \mathrm{C}$ with a $12 \mathrm{~h}$ day length. Each genotype was represented by four plants. Matured siliques were harvested individually by hand in the middle of June for each combination, and after siliques were dried, seeds were extracted and counted.

\subsection{Assessment of the Ploidy Level}

\subsubsection{Flow Cytometry Analysis (FCM)}

The nuclear DNA content was evaluated for parental lines and hybrids using FCM according to the method reported previously [31]. Leaf fragments $\left(0.5 \mathrm{~cm}^{2}\right)$ were cut with a razor blade in a Petri dish that contained $0.5 \mathrm{~mL}$ nuclei isolation Partec buffer supplemented with propidium iodide $\left(50 \mathrm{mg} \cdot \mathrm{mL}^{-1}\right)$ and RNase $\left(50 \mathrm{mg} \cdot \mathrm{mL}^{-1}\right)$. The young leaves of Zea mays CE-777 ( $2 \mathrm{C}=5.43 \mathrm{pg}$ DNA) were used as an internal standard. After chopping, $1.5 \mathrm{~mL}$ of the isolation buffer was added, and the samples were filtered through a $30 \mu \mathrm{m}$ filter and incubated at room temperature for 15-30 min in the dark. Nuclei fluorescence was measured using a CyFlow Ploidy Analyser with CyView software (CyFlow PA, Partec, Germany) with an Nd-YAG green laser at $532 \mathrm{~nm}$. Data were analysed using CyView software (CyFlow PA, Partec, Germany). Samples with at least 5000 nuclei were measured from five leaves of each plant, with two runs per nuclei isolation extract. The 2C DNA content of each sample was calculated as the sample peak mean divided by the standard plant peak and multiplied by the value of the nuclear DNA content of the standard plant.

\subsubsection{Chromosome Count}

Cytogenetic observation was performed according to Marasek-Ciolakowska et al. [32]. Root tips were treated with $2 \mathrm{mM}$ 8-hydroxyquinoline for $4 \mathrm{~h}$, fixed in 3:1 ethanol:glacial acetic acid solution for at least $12 \mathrm{~h}$, and then digested in a mixture of enzymes comprised of 20\% pectinase (Sigma-Aldrich, St. Louis, MO, USA), 1\% cellulase (Calbiochem, San Diego, CA, USA), and 1\% cellulose 'Onozuka R-10' (Duchefa, Haarlem, The Netherlands) at $37{ }^{\circ} \mathrm{C}$ for $1 \mathrm{~h}$. Root meristems were squashed in a drop of $45 \%(v / v)$ acetic acid. After freezing in liquid nitrogen, cover slips were removed using a razor blade, and the preparations were dehydrated in absolute ethanol, air dried, and stored at $-20{ }^{\circ} \mathrm{C}$. The preparations were stained with $2.5 \mathrm{~g} / \mathrm{mL} \mathrm{4}$,6-diamidino-2-phenylindole (DAPI) (Serva, Heidelberg, Germany) and closed in glycerol. For each genotype, at least 5 instances of metaphase were photographed with a digital CCD camera PS-Fi1 (Nikon, Tokyo, Japan) attached to an epifluorescent microscope Optiphot-2 (Nikon, Jappan) using UV excitation for DAPI visualisation.

\subsection{Analysis of the Morphological Characteristics}

The morphological characteristics during the vegetative and reproductive stages of $2 \mathrm{~F}_{1}$ hybrids, $4 \mathrm{~F}_{2}$ hybrids, and their parental components were evaluated. At the beginning of April, measurements of the leaf surface were made using a surface scanner AM350 (Geomor Technik, Szczecin, Poland). Bud length, flower size, size of median and lateral nectaries, fertility/sterility, pod length, and number of seeds per pod of the vernalised hybrids and their parents were analysed during the generative phase. Measurements of flower diameter and size of flower components (nectary, anther, pistil, and stamen) were determined for 5 flowers under a stereo microscope SZX16 (Olympus, Tokyo, Japan) with imaging software Cell (Olympus, Münster, Germany).

\subsection{Pollen Grain Diameter and Viability}

A mixed sample of pollen from 3-6 mature anthers were stained according to Alexander [33]. The pollen grain diameter was evaluated for 100 grains with three repetitions. Pollen viability was determined based on pollen stainability with Alexander's stain in 5 fields of view at $100 \times$ magnification. Pollen grain diameter and viability were assessed using a light microscope (Eclipse 80i, Nikon, Tokyo, Japan) with imaging software NISElements Br ver. 2.30 (Nikon Instruments Inc., Tokyo, Japan) for photo documentation and measurements. 


\subsection{Leaf Anatomy}

In a histological study, $10 \times 5 \mathrm{~mm}$ fragments of the third, fully developed leaves were sampled. Five samples were collected for each genotype. The material was fixed in a chromic acid, acetic acid, and formalin ( $\mathrm{CrAF}$ ) mixture for $48 \mathrm{~h}$ at room temperature, dehydrated in graded series of ethanol $(70,80,90$, and $100 \%)$, and embedded in paraffin according to a previously reported method [34]. Cross sections (10 $\mu \mathrm{m}$ thick) were cut with a rotary microtome (Leica, Wetzlar, Germany) and stained with safranin ( $1 \%$ prepared in ultrapure water) and fast green (1\% prepared in $95 \%$ ethanol). The sections were observed under a light microscope as described for pollen analysis (see above). For each sample, the thickness of the lamina, abaxial and adaxial epidermal layer, and spongy and palisade mesophyll were determined. For statistical analysis, three replicates were used for each genotype, and each replicate consisted of 20 measurements.

\subsection{Stomata Length and Density}

Samples of the abaxial epidermis from the middle part of the third fully developed leaf were isolated and stained with toluidine blue according to Dyki and Habdas [35]. For each genotype, the number of stomata per $1 \mathrm{~mm}^{2}(\mathrm{n}=3$ replication/genotype $)$ and length of stomata ( $\mathrm{n}=3$ replications $\times 100$ stomata/genotype) were determined at 100 and $400 \times$ magnification, respectively, using a Nikon Eclipse 80i microscope (Eclipse 80i, Nikon, Tokyo, Japan) with the program NIS-Elements BR ver. 2.30 (Nikon Instruments Inc., Tokyo, Japan).

\subsection{Statistical Analyses}

The nuclear DNA content, pollen grain diameter and viability, leaf surface, bud length, flower diameter, pistil and stamen size, size of median and lateral nectary, pod length, stomata length and density, thickness of the lamina, thickness of the abaxial and adaxial epidermal layer, and thickness of the spongy and palisade mesophyll were subjected to a one-way analysis of variance (STATISTICA package StatSoft v. 10, Dell Inc. Round Rock, TX, USA). The means were compared using Tukey's test at $p=0.05$. Standard deviations for nuclear DNA content, leaf surface, bud length, pistil and stamen size, nectaries and pod length were calculated in 5 replications $(n=5)$, whereas standard deviations for pollen grain diameter, thickness of the lamina and epidermal layers, and thickness of the spongy and palisade mesophyll, stomata length and density were calculated in 3 replications $(n=3)$.

\section{Results}

\subsection{Genome Size Determination by FCM and Somatic Chromosome Count}

The ploidy levels of parental lines and hybrids were determined by flow cytometry (FCM) analysis and chromosome count (Figures 2 and 3, Table 1). The amount of nuclear DNA and the number of chromosomes in parental lines of B. napus and B. oleracea agreed with data found in the literature. Head cabbage IW1234 (B. oleracea L. var. capitata) and kale IW08 (B. oleracea L. var. acephala) are diploids with $2 \mathrm{n}=18$ chromosomes and a DNA volume of 1.48 and $1.51 \mathrm{pg} 2 \mathrm{C}$, respectively. Allotetraploid rapeseed RAP62 (B. napus L.) had 38 chromosomes and a significantly higher amount of DNA (2.49 pg) than B. oleracea genotypes. The $\mathrm{F}_{1}$ hybrids of head cabbage $\times$ rapeseed (S3) and kale $\times$ rapeseed crosses (S20) were allotriploids with $2 n=28$ chromosomes; the nuclear DNA content was intermediate to the genome size of progenitors (1.97 and $1.99 \mathrm{pg}$, respectively). In interspecific hybrids of the $\mathrm{F}_{2}$ generation, which were derived after self-pollination of $\mathrm{F}_{1}$ hybrids (FS3, FS20) or by open crosses between plants of the $\mathrm{F}_{1}$ generation (FC320, FC230), chromosome numbers were similar $(2 \mathrm{n}=56$ or $2 \mathrm{n}=55)$, whereas genome sizes varied between $3.81 \pm 0.10 \mathrm{pg} 2 \mathrm{C}$ for FS20 and $3.95 \pm 0.091 \mathrm{pg} 2 \mathrm{C}$ for FC230. 


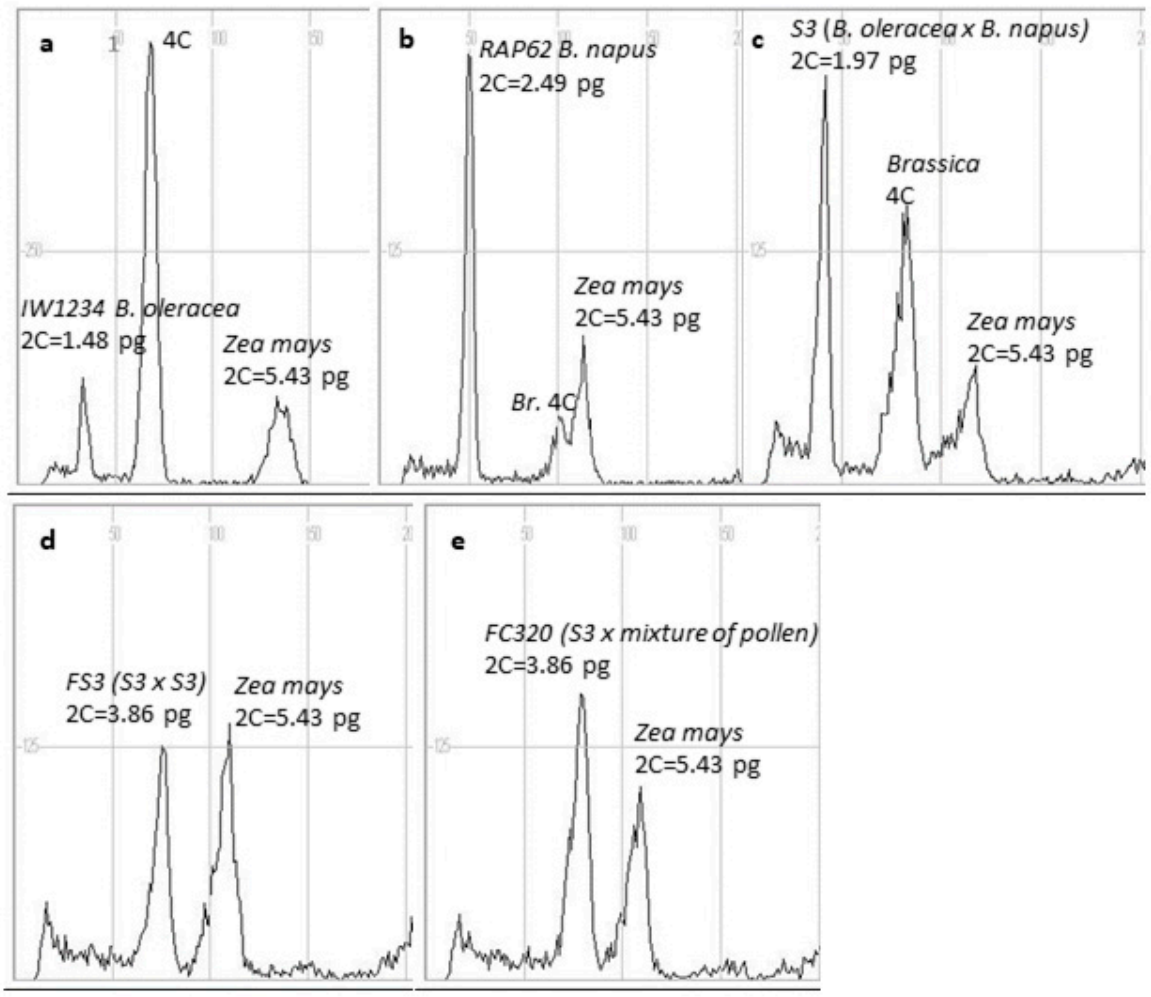

Figure 2. Histograms of nuclear DNA estimation using flow cytometry (FCM) for Brassica oleracea and hybrids with internal standard Zea mays (2C DNA $=5.43$ pg). (a) IW1234 B. oleracea L. var. capitata (head cabbage); (b) RAP62 B. napus (rapeseed); (c) S3 $\mathrm{F}_{1}$ (head cabbage $\times$ rapeseed); (d) FS3 $\mathrm{F}_{2}$ $(\mathrm{S} 3 \times \mathrm{S} 3) ;(\mathbf{e}) \mathrm{FC} 320 \mathrm{~F}_{2}(\mathrm{~S} 3 \times$ mixture of pollen $)$.

Table 1. Nuclear DNA content and chromosome number of parental Brassica napus and B. oleracea lines and their interspecific hybrids in the $\mathrm{F}_{1}$ and $\mathrm{F}_{2}$ generation.

\begin{tabular}{|c|c|c|c|c|}
\hline Genotype & Genome & $\begin{array}{c}\text { DNA } \\
\text { Content (pg) }\end{array}$ & Std. dev. & $\begin{array}{c}\text { Chromosome } \\
\text { Number }\end{array}$ \\
\hline IW1234 \& head cabbage & $\mathrm{CC}$ & $1.48 \mathrm{~d}^{*}$ & 0.021 & 18 \\
\hline IW08 \& kale & $\mathrm{CC}$ & $1.51 \mathrm{~d}$ & 0.022 & 18 \\
\hline RAP62 क्ष rapeseed & AACC & $2.49 \mathrm{~b}$ & 0.036 & 38 \\
\hline \multicolumn{5}{|c|}{ Interspecific hybrids of the $F_{1}$ generation } \\
\hline S3 (head cabbage $\times$ rapeseed) & $\mathrm{ACC}$ & $1.97 \mathrm{c}$ & 0.030 & 28 \\
\hline S20 $($ kale $\times$ rapeseed $)$ & ACC & $1.99 \mathrm{c}$ & 0.017 & 28 \\
\hline \multicolumn{5}{|c|}{ Interspecific hybrids of the $F_{2}$ generation } \\
\hline FS3 $(\mathrm{S} 3 \times \mathrm{S} 3)$ & AACCCC & $3.86 \mathrm{a}$ & 0.034 & 56 \\
\hline $\mathrm{FS} 20(\mathrm{~S} 20 \times \mathrm{S} 20)$ & AACCCC & $3.81 \mathrm{a}$ & 0.102 & 55 \\
\hline FC320 (S3 × mixture of pollen) & AACCCC & $3.86 \mathrm{a}$ & 0.141 & 56 \\
\hline FC230 $($ S20 $\times$ mixture of pollen & AACCCC & $3.95 \mathrm{a}$ & 0.091 & 55 \\
\hline
\end{tabular}

* Means in the columns followed by the same lowercase letters are not significantly different according to Tukey's test at $p=0.05$. \& maternal line; of pollen donor. 

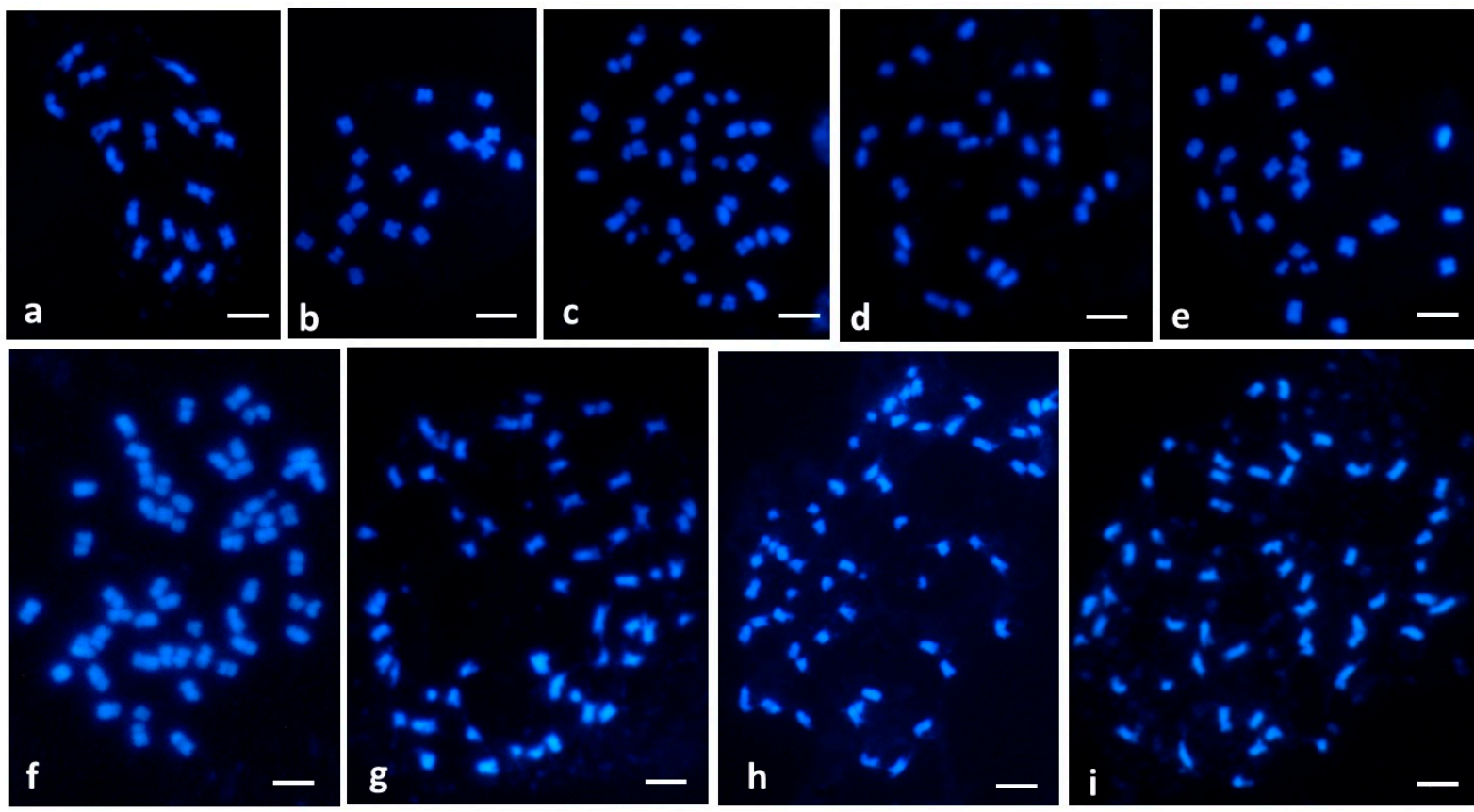

Figure 3. Chromosome counts of Brassica genotypes. (a) IW1234 B. oleracea L. var. capitata (head cabbage), $2 \mathrm{n}=18$; (b) IW08 B. oleracea L. var. acephala (kale), 2n =18; (c) RAP62 B. napus (rapeseed), $2 \mathrm{n}=38 ;(\mathbf{d}) \mathrm{S} 3 \mathrm{~F}_{1}$ (head cabbage $\times$ rapeseed), $2 \mathrm{n}=28 ;(\mathbf{e}) \mathrm{S} 20 \mathrm{~F}_{1}$ (kale $\times$ rapeseed), $2 \mathrm{n}=28$; (f) FS3 $\mathrm{F}_{2}$ $(\mathrm{S} 3 \times \mathrm{S} 3), 2 \mathrm{n}=56$; (g) FS20 F $(\mathrm{S} 20 \times \mathrm{S} 20), 2 \mathrm{n}=55 ;(\mathrm{h})$ FC320 $\mathrm{F}_{2}(\mathrm{~S} 3 \times$ mixture of pollen $), 2 \mathrm{n}=55$; (i) FC230 $\mathrm{F}_{2}(\mathrm{~S} 20 \times$ mixture of pollen $), 2 \mathrm{n}=55$. Scale bars represent $5 \mu \mathrm{m}$.

3.2. Characteristics of Parental Genotypes and Interspecific Hybrids of the $F_{1}$ and $F_{2}$ Generations in the Generative Stage

In the generative stage, interspecific polyploids of the $F_{1}$ and $F_{2}$ generation displayed significant heterosis with respect to flower morphology, nectary size, fertility, and ability to set seeds compared to the parent genotypes (Figure 4 and Figure S1). Allohexaploids representing $\mathrm{F}_{2}$ hybrids had significantly longer buds, flower diameters, and longer anthers than those of parental B. napus and B. oleracea lines and triploid $\mathrm{F}_{1}$ hybrids (Table 2). There were no significant differences in the length of the pistils. Each Brassica flower had two pairs of nectaries, the lateral (inner) and median (outer) pairs, that differed in morphology, size, and nectar productivity (Table 2, Figure 4c and Figure S1). The lateral nectaries were of equal size in B. oleracea L. var. capitata and B. napus, and they were shorter by approximately $20 \%$ compared to B. oleracea L. var. acephala. In contrast, there was no significant difference in the length of median nectaries among parental lines and interspecific hybrids. Lateral nectaries of the $\mathrm{F}_{1}$ generation had a similar size to parental lines, but they were shorter by $30 \%$ than lateral nectaries of the $\mathrm{F}_{2}$ generation (Table 2). Pollen viability was high in parental lines and varied from $85 \%$ in kale to $99 \%$ in rapeseed, and their average pollen size was 24.54 and $29.86 \mu \mathrm{m}$, respectively. All interspecific hybrids of the $\mathrm{F}_{1}$ and $\mathrm{F}_{2}$ generations developed male-fertile flowers. In triploid $\mathrm{F}_{1}$ hybrids, pollen viability was low, and only 6.76 (S3) and 13.46\% (S20) of pollen grains were stained by Alexander's solution (Figures $4 \mathrm{e}$ and S1, Table 2). In interspecific hybrids of the $\mathrm{F}_{2}$ generation, pollen viability was comparable to the parental genotypes and varied from 75.38 (FS3) to $88.24 \%$ (FC320). The average pollen lengths for the interspecific hybrids of the $F_{1}$ and $F_{2}$ generations were significantly larger compared to the parental lines (Table 2, Figure S1). The distribution of pollen size was similar for the hybrids of head cabbage (Figure 5a) and kale (Figure 5b). A high variation in the size of viable pollen was recorded for $F_{1}$ hybrids, whose length differed from 19.40 to $36.10 \mu \mathrm{m}$ in S3 (head cabbage $\times$ rapeseed) and from 20.85 to $32.40 \mu \mathrm{m}$ in S20 (kale $\times$ rapeseed) hybrids (Figure 5). Among parental genotypes, differences in seed set and pod length were observed, where rapeseed produced longer pods by approximately 
$10 \%$ and more seeds than parental lines of B. oleracea. The negative effect on the length of pods and seed set was observed especially in the interspecific hybrid of the $\mathrm{F}_{1}$ generation, in which pods were approximately $70 \%$ shorter compared to parental lines, and they were usually empty (Table 2, Figure $4 \mathrm{~h}$ ). Hybrids of the $\mathrm{F}_{2}$ generation produced longer pods, and most of them had more seeds per pod than hybrids of the $\mathrm{F}_{1}$ generation. However, among the $\mathrm{F}_{2}$ hybrids, differences in the number of seeds were observed depending on the pollinator. Interspecific hybrids of the $\mathrm{F}_{2}$ generation derived by open crosses between plants of the $F_{1}$ generation (FC320, FC230) had better seed set compared to $F_{2}$ hybrids derived from the self-pollination of $\mathrm{F}_{1}$ hybrids (FS3, FS20) (Table 2).
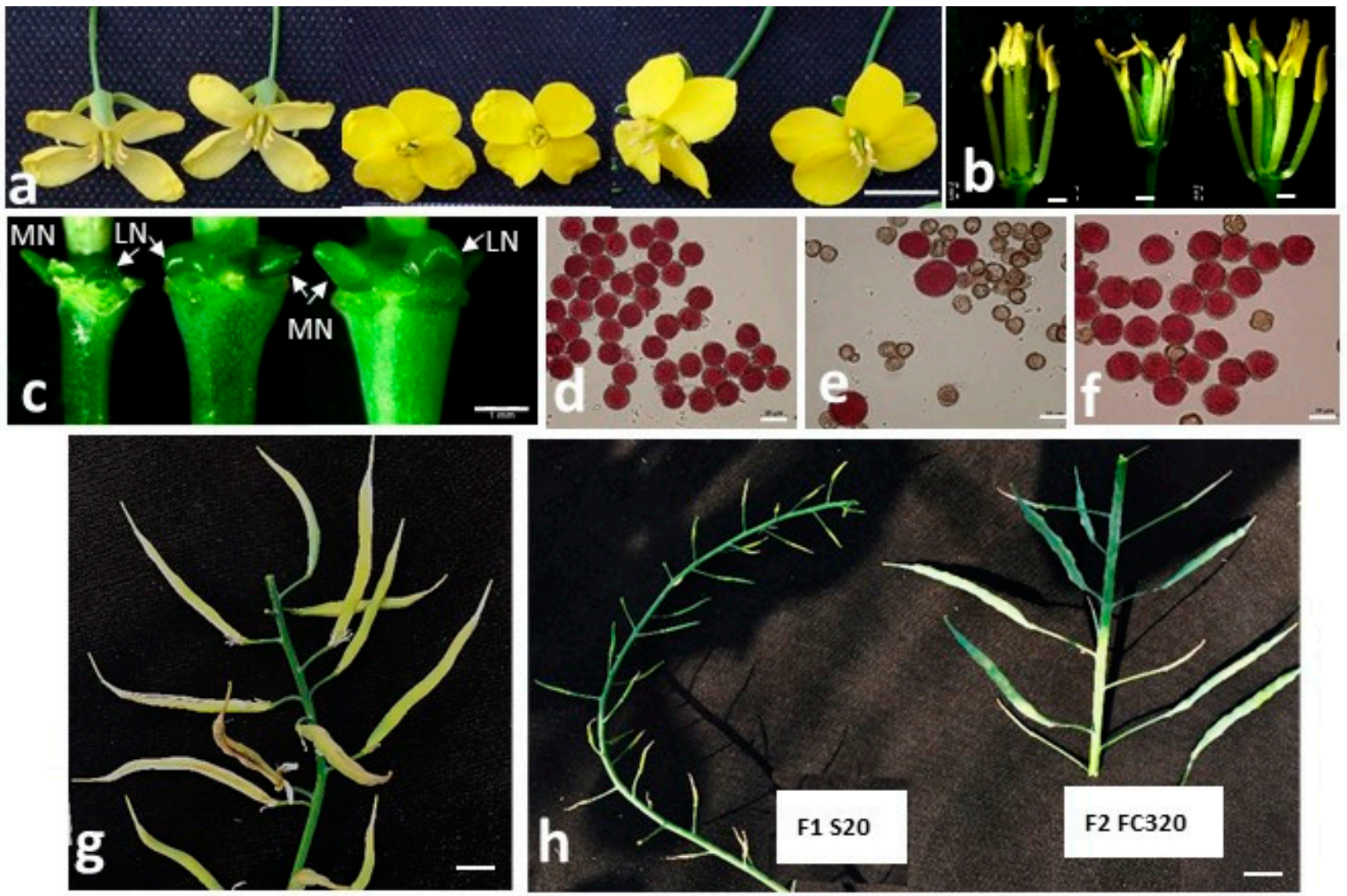

Figure 4. Phenotypic characteristics of maternal line IW1234 and the interspecific hybrids of head cabbage $\times$ rapeseed in the $F_{1}$ and $F_{2}$ generations in the generative stage. (a) Flowers of head cabbage IW1234 (left), S3 F 1 (head cabbage $\times$ rapeseed) (middle) and FC320 $\mathrm{F}_{2}(\mathrm{~S} 3 \times$ mixture of pollen) (right, Bar = $1 \mathrm{~cm}$; (b) Flowers with removed sepals and petals of head cabbage IW1234 (left), S3 $\mathrm{F}_{1}$ (middle) and FC320 $\mathrm{F}_{2}$ (right), Bar $=2 \mathrm{~mm}$; (c) Receptacles with lateral and median nectaries, head cabbage IW1234 (left), S3 F 1 (middle) and FC320 F (right), MN-median nectary, LN-lateral nectary, Bar = $1 \mathrm{~mm}$; (d-f) Pollen staining with Alexander's solution, Bar = $25 \mu \mathrm{m}$; (d) IW1234; (e) S3 $\mathrm{F}_{1}$ (f) FC320 F $\mathrm{F}_{2}$ (g) Pod of head cabbage IW1234; (h) Pod of S20 F 1 and FC320 F generations. Scale bars represent $1 \mathrm{~cm}(\mathrm{~g}, \mathbf{h})$. 
Table 2. Comparison of phenotypic characteristics of parental genotypes and interspecific hybrids of the $F_{1}$ and $F_{2}$ generations at the generative stage.

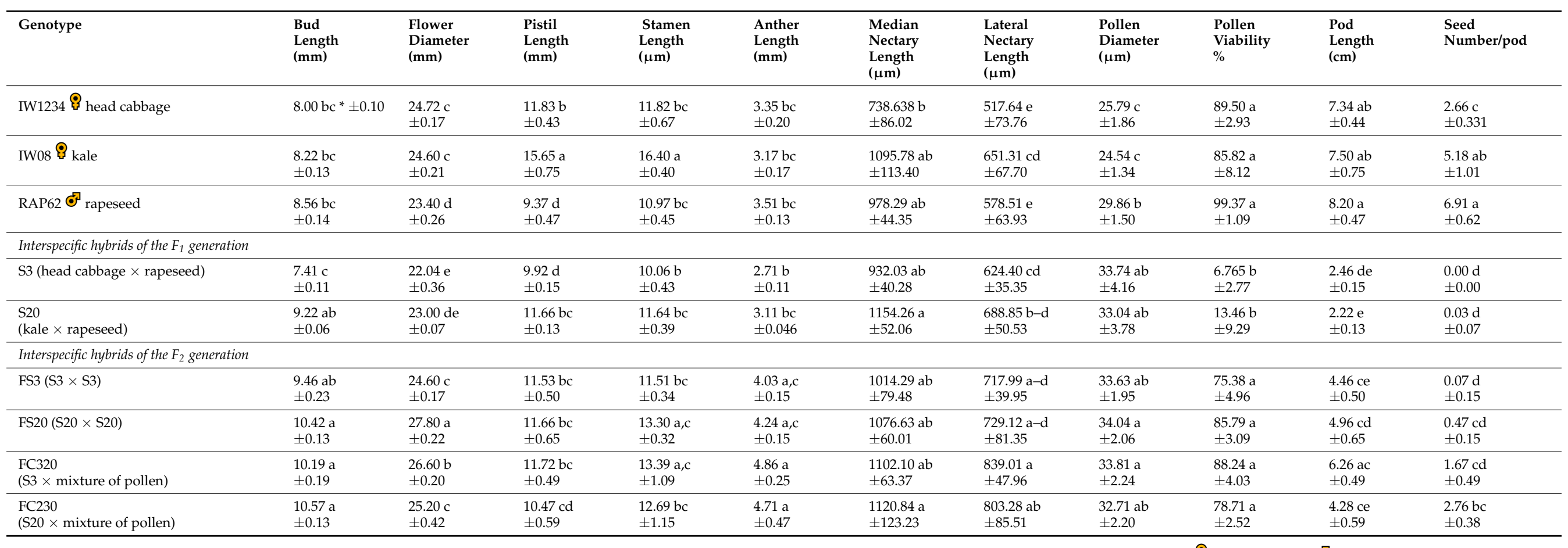

* Means in the columns followed by the same lower case letters are not significantly different according to Tukey's test at $p=0.05$. \& maternal line; $\odot$ pollen donor. 

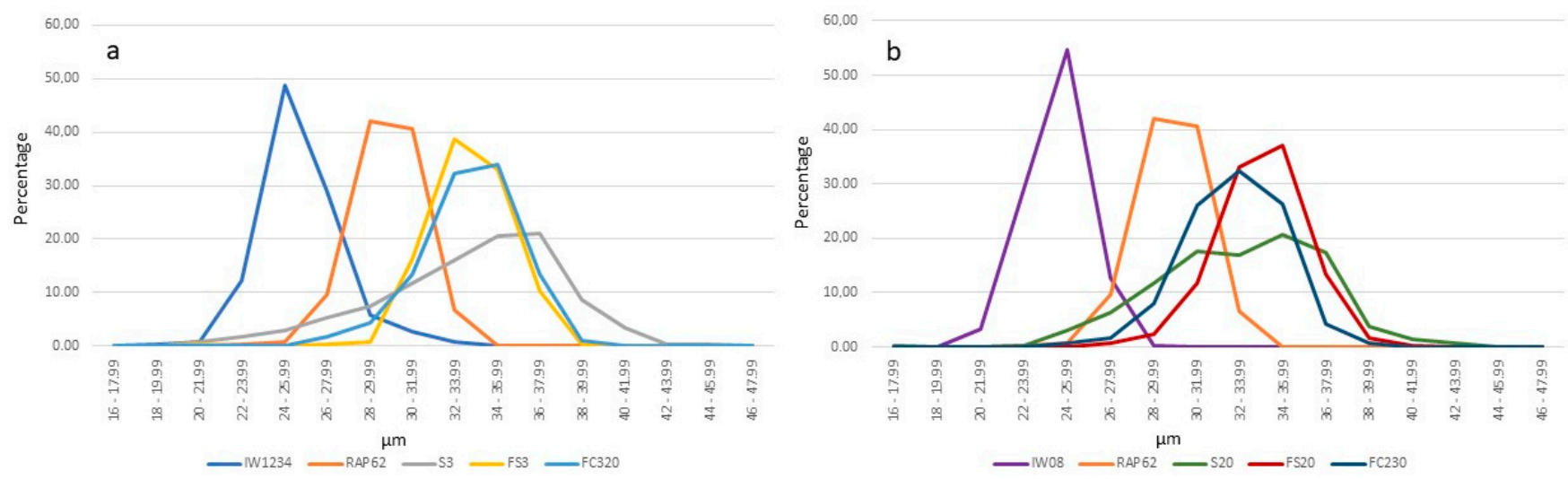

Figure 5. Distribution of pollen grain sizes (\%) in parental genotypes and interspecific hybrids. (a) Head cabbage IW1234, rapeseed RAP62, S3F1 (head cabbage $\times$ rapeseed), FS3 F2 (S3 $\times$ self), and FS320 F2 (S3 $\times$ mixture of pollen). (b) Kale IW08, rapeseed RAP62, S20 F1 (kale $\times$ rapeseed), FS20 $(\mathrm{S} 20 \times$ self $)$, and FS230F2 $($ S20 $\times$ mixture of pollen).

3.3. Characteristics of Morphological and Anatomical Traits of Leaves of Parental Genotypes and the Interspecific Hybrids of the $F_{1}$ and $F_{2}$ Generations

The morphological and anatomical characteristics of the leaves of $F_{1}$ and $F_{2}$ hybrids were compared with those of parental genotypes (Table 3). Allohexaploid hybrids of the $F_{2}$ generation had bigger and thicker leaves than triploids of the $F_{1}$ generation and parental lines of B. oleracea and B. napus (Figure 6a and Figure S2). The largest leaf surface and thickest leaves were observed in FC320, which resulted from open pollination of $\mathrm{F}_{1} \mathrm{~S} 3$ hybrids; the leaves were larger than leaves of head cabbage and $\mathrm{F}_{1} \mathrm{~S} 3$ hybrids by approximately $250 \%$ and thicker by $50-60 \%$. Similarly, the comparison of the abaxial epidermis (Figure $6 \mathrm{~b}-\mathrm{d}$ and Figure $\mathrm{S} 2 \mathrm{~b}-\mathrm{j}$ ) showed that hexaploid $\mathrm{F}_{2}$ hybrids had larger stomata than triploids of the $\mathrm{F}_{1}$ generation and parental lines of B. oleracea and B. napus, but their density per $\mathrm{mm}^{2}$ was the lowest. Figure 7 shows that in the diploid parental lines of $B$. oleracea, approximately $42 \%$ of head cabbage stomata and kale stomata had sizes of 24-26 and 22-24 $\mu \mathrm{m}$ in length, respectively. In tetraploid B. napus, there was significant variation in stomata length, which differed from 7.07 to $32.76 \mu \mathrm{m}$, and approximately $20 \%$ of stomata had a length of $24-26 \mu \mathrm{m}$. In the $\mathrm{F}_{1}$ generation, $28 \%$ of stomata of head cabbage and $37 \%$ of kale stomata had a length of $26-28 \mu \mathrm{m} . \mathrm{F}_{2}$ hybrids of kale (FS20, FC230) had a similar stomata size distribution, and about $30 \%$ of them had lengths from 30 to $36 \mu \mathrm{m} . \mathrm{F}_{2}$ hybrids of head cabbage showed high variation in stomata sizes. Approximately $26 \%$ of FS3 hybrids had stomata 32-34 $\mu \mathrm{m}$ in length, and 28\% of FC320 hybrids had stomata 36-38 $\mu \mathrm{m}$ in length. Histological analysis of leaf fragment cross sections revealed high variation among genotypes with respect to the internal structure of leaves (Figures $6 \mathrm{e}-\mathrm{g}$ and S2k-s). In general, the thickness of the abaxial and adaxial epidermis was higher in interspecific hybrids of the $F_{2}$ generation derived after self-pollination of $F_{1}$ hybrids $\left(F_{2}\right.$ FS3, FS20) compared to $\mathrm{F}_{2}$ hybrids obtained by open crosses between plants of the $\mathrm{F}_{1}$ generation (FC320, FC230). The thickness of the adaxial epidermis was similar in the $\mathrm{F}_{1}$ generation and the parental lines; similarly, there was no relationship between ploidy level and the thickness of the abaxial epidermis among parental lines and $F_{1}$ hybrids (Table 3 ). The cells of the epidermis differed in shape and size, which were tightly arranged into a single layer. The characteristic feature of both head cabbage and kale hybrids was the presence of large, strongly vacuolated cells among smaller ones in the epidermal layer. Layers of both the palisade and spongy mesophyll were significantly thicker in hexaploids of the $\mathrm{F}_{2}$ generation. In general, the examined genotypes differed in the thickness of particular cell layers in leaves, which was related to the thickness of the lamina. Leaves of FC320 $\mathrm{F}_{2}$ hybrids were characterised by a more compact mesophyll structure with smaller intercellular spaces than other genotypes (Figure 6e-g and Figure S1k-s). 
Table 3. Comparison of morphological and anatomical characteristics of leaves of parental genotypes and the interspecific hybrids of the $F_{1}$ and $F_{2}$ generations.

\begin{tabular}{|c|c|c|c|c|c|c|c|c|}
\hline Genotype & $\begin{array}{l}\text { Leaf } \\
\text { Surface } \\
\left(\mathrm{cm}^{2}\right)\end{array}$ & $\begin{array}{l}\text { Leaf } \\
\text { Thickness } \\
(\mu \mathrm{m})\end{array}$ & $\begin{array}{l}\text { Palisade Mesophyll } \\
\text { Thickness }(\mu \mathrm{m})\end{array}$ & $\begin{array}{l}\text { Spongy Mesophyll } \\
\text { Thickness }(\mu \mathrm{m})\end{array}$ & $\begin{array}{l}\text { Abaxial } \\
\text { Epidermis } \\
(\mu \mathrm{m})\end{array}$ & $\begin{array}{l}\text { Adaxial } \\
\text { Epidermis } \\
(\mu \mathrm{m})\end{array}$ & $\begin{array}{l}\text { Stomata Length } \\
(\mu \mathrm{m})\end{array}$ & $\begin{array}{l}\text { Stomata Density } \\
\left(\mathrm{No} / \mathrm{mm}^{2}\right)\end{array}$ \\
\hline IW1234 8 head cabbage & $\begin{array}{l}164.50 c^{*} \\
\pm 9.43\end{array}$ & $\begin{array}{l}264.60 \mathrm{~cd} \\
\pm 19.63\end{array}$ & $\begin{array}{l}103.3 \mathrm{bc} \\
\pm 15.56\end{array}$ & $\begin{array}{l}113.9 \text { c-e } \\
\pm 16.48\end{array}$ & $\begin{array}{l}20.42 \mathrm{bc} \\
\pm 0.65\end{array}$ & $\begin{array}{l}15.53 \mathrm{bd} \\
\pm 2.65\end{array}$ & $\begin{array}{l}24.38 \mathrm{~b} \\
\pm 0.07\end{array}$ & $\begin{array}{l}114.11 \text { ce } \\
\pm 6.26\end{array}$ \\
\hline IW08 \& kale & $\begin{array}{l}85.24 \mathrm{c} \\
\pm 8.61\end{array}$ & $\begin{array}{l}234.30 \mathrm{~d} \\
\pm 14.33\end{array}$ & $\begin{array}{l}93.6 \mathrm{c} \\
\pm 13.61\end{array}$ & $\begin{array}{l}103.5 \mathrm{c}-\mathrm{f} \\
\pm 15.93\end{array}$ & $\begin{array}{l}15.43 \mathrm{~d} \\
\pm 1.47\end{array}$ & $\begin{array}{l}13.24 \mathrm{~d} \\
\pm 1.68\end{array}$ & $\begin{array}{l}22.34 \mathrm{~b} \\
\pm 0.54\end{array}$ & $\begin{array}{l}271.22 \mathrm{a} \\
\pm 13.80\end{array}$ \\
\hline RAP62 $\sigma^{g}$ rapeseed & $\begin{array}{l}137.54 \mathrm{c} \\
\pm 12.76\end{array}$ & $\begin{array}{l}232.32 \mathrm{~d} \\
\pm 21.08\end{array}$ & $\begin{array}{l}91.96 \mathrm{c} \\
\pm 12.30\end{array}$ & $\begin{array}{l}92.6 \mathrm{f} \\
\pm 15.68\end{array}$ & $\begin{array}{l}20.05 \mathrm{c} \\
\pm 2.90\end{array}$ & $\begin{array}{l}15.86 \text { bd } \\
\pm 1.73\end{array}$ & $\begin{array}{l}23.54 \mathrm{~b} \\
\pm 4.12\end{array}$ & $\begin{array}{l}181.33 \mathrm{~b} \\
\pm 18.28\end{array}$ \\
\hline \multicolumn{9}{|c|}{ Interspecific hybrids of the $F_{1}$ generation } \\
\hline S3 (head cabbage $\times$ rapeseed) & $\begin{array}{l}165.58 \mathrm{c} \\
\pm 18.91\end{array}$ & $\begin{array}{l}249.14 \mathrm{~cd} \\
\pm 17.17\end{array}$ & $\begin{array}{l}114.1 \mathrm{bc} \\
\pm 15.65\end{array}$ & $\begin{array}{l}94 \text { ef } \\
\pm 16.28\end{array}$ & $\begin{array}{l}21.26 \mathrm{bc} \\
\pm 2.05\end{array}$ & $\begin{array}{l}15.16 \mathrm{~cd} \\
\pm 1.82\end{array}$ & $\begin{array}{l}26.89 \mathrm{~b} \\
\pm 1.28\end{array}$ & $\begin{array}{l}140.78 \text { bc } \\
\pm 10.58\end{array}$ \\
\hline S20 $($ kale $\times$ rapeseed $)$ & $\begin{array}{l}133.20 \mathrm{c} \\
\pm 26.13\end{array}$ & $\begin{array}{l}294.83 \mathrm{bc} \\
\pm 16.88\end{array}$ & $\begin{array}{l}129.6 \mathrm{bc} \\
\pm 15.31\end{array}$ & $\begin{array}{l}123.6 \text { bd } \\
\pm 15.54\end{array}$ & $\begin{array}{l}19.23 \mathrm{~cd} \\
\pm 1.38\end{array}$ & $\begin{array}{l}14.99 \mathrm{~cd} \\
\pm 1.65\end{array}$ & $\begin{array}{l}26.87 \mathrm{~b} \\
\pm 0.66\end{array}$ & $\begin{array}{l}120.89 \mathrm{~cd} \\
\pm 5.83\end{array}$ \\
\hline \multicolumn{9}{|c|}{ Interspecific hybrids of the $F_{2}$ generation } \\
\hline FS3 $(\mathrm{S} 3 \times \mathrm{S} 3)$ & $\begin{array}{l}346.50 \mathrm{~b} \\
\pm 9.24\end{array}$ & $\begin{array}{l}327.91 \mathrm{~b} \\
\pm 12.73\end{array}$ & $\begin{array}{l}138.3 \mathrm{~b} \\
\pm 18.66\end{array}$ & $\begin{array}{l}138 \mathrm{~b} \\
\pm 14.38\end{array}$ & $\begin{array}{l}26.05 \mathrm{a} \\
\pm 4.08\end{array}$ & $\begin{array}{l}22.47 \mathrm{a} \\
\pm 2.82\end{array}$ & $\begin{array}{l}32.66 \mathrm{a} \\
\pm 0.39\end{array}$ & $\begin{array}{l}87.88 \text { ce } \\
\pm 1.39\end{array}$ \\
\hline FC320 (S3 × mixture of pollen) & $\begin{array}{l}603.72 \mathrm{a} \\
\pm 13.03 \\
\end{array}$ & $\begin{array}{l}409.60 \mathrm{a} \\
\pm 28.72 \\
\end{array}$ & $\begin{array}{l}183 \mathrm{a} \\
\pm 26.25\end{array}$ & $\begin{array}{l}180.1 \mathrm{a} \\
\pm 24.76\end{array}$ & $\begin{array}{l}17.84 \mathrm{~cd} \\
\pm 2.40\end{array}$ & $\begin{array}{l}17.50 \mathrm{bd} \\
\pm 2.80\end{array}$ & $\begin{array}{l}32.50 \mathrm{a} \\
\pm 1.33\end{array}$ & $\begin{array}{l}104.00 \text { ce } \\
\pm 3.34\end{array}$ \\
\hline FC230 (S20 $\times$ mixture of pollen $)$ & $\begin{array}{l}372.34 \mathrm{~b} \\
\pm 20.35\end{array}$ & $\begin{array}{l}294.76 \text { bc } \\
\pm 14.07\end{array}$ & $\begin{array}{l}119.6 \mathrm{bc} \\
\pm 10.91\end{array}$ & $\begin{array}{l}129.9 \mathrm{bc} \\
\pm 14.33\end{array}$ & $\begin{array}{l}24.24 \mathrm{ab} \\
\pm 1.31\end{array}$ & $\begin{array}{l}19.32 \mathrm{ac} \\
\pm 2.98\end{array}$ & $\begin{array}{l}37.40 \mathrm{a} \\
\pm 1.29\end{array}$ & $\begin{array}{l}55.13 \mathrm{e} \\
\pm 3.29\end{array}$ \\
\hline
\end{tabular}

* Means in the columns followed by the same lowercase letters are not significantly different according to Tukey's test at $p=0.05$. \& maternal line; ${ }^{\circ}$ pollen donor. 

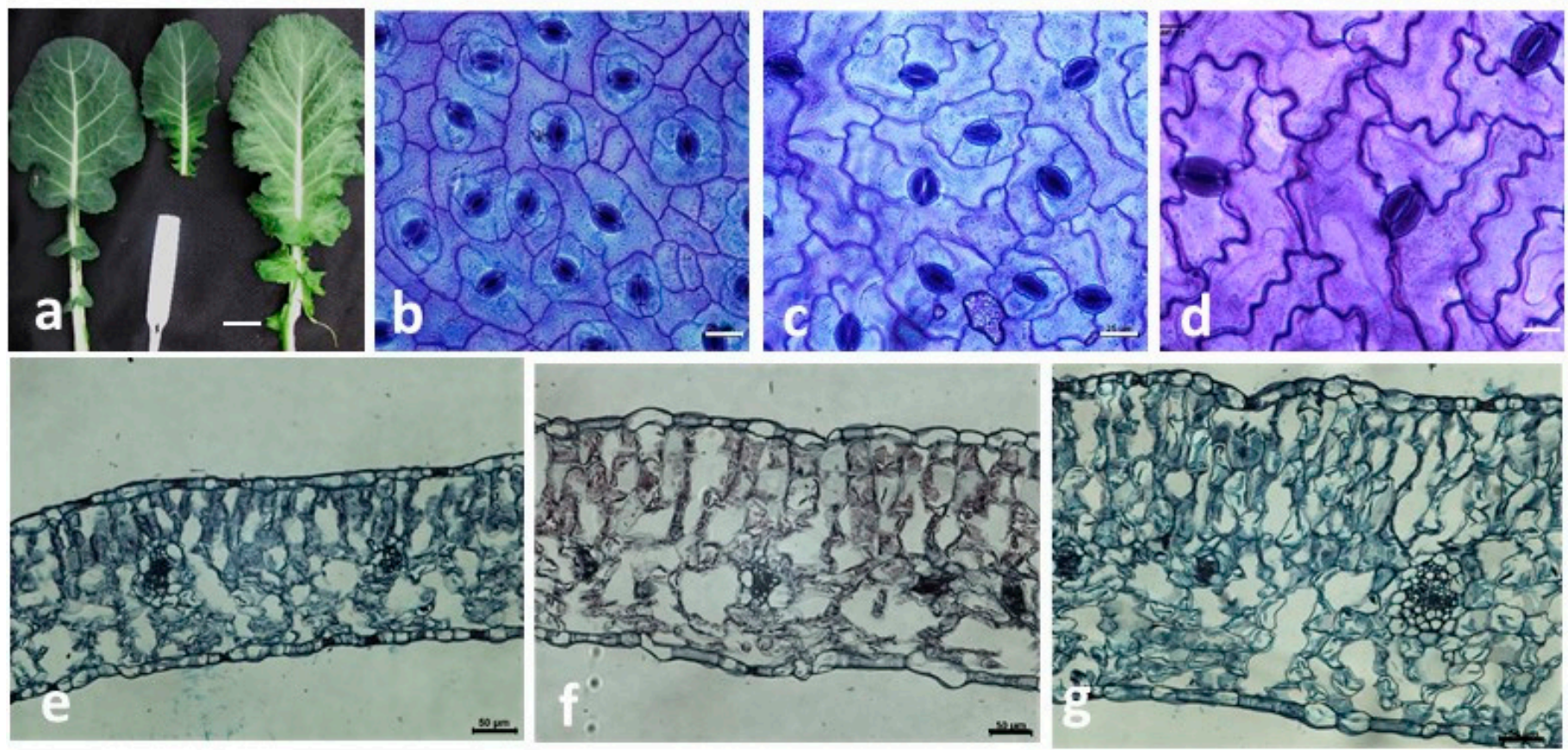

Figure 6. Characteristics of morphological and anatomical traits of leaves of maternal line IW1234 and the interspecific hybrids of head cabbage $\times$ rapeseed in the $F_{1}$ and $F_{2}$ generations. (a) Leaf of maternal genotype IW1234 (middle) and $\mathrm{F}_{2}$ generation FS3 (left), FC320 F 2 (right), Bar = 2 cm; (b-d) Stomata on the abaxial leaf surface, Bars = $25 \mu \mathrm{m}$; (b) IW1234; (c) F 1 S3; (d) FC320 F ; (e-g) Leaf cross-section, Bars = $50 \mu \mathrm{m}$; (e) IW1234; (f) F 1 S3; (g) FC320 F .
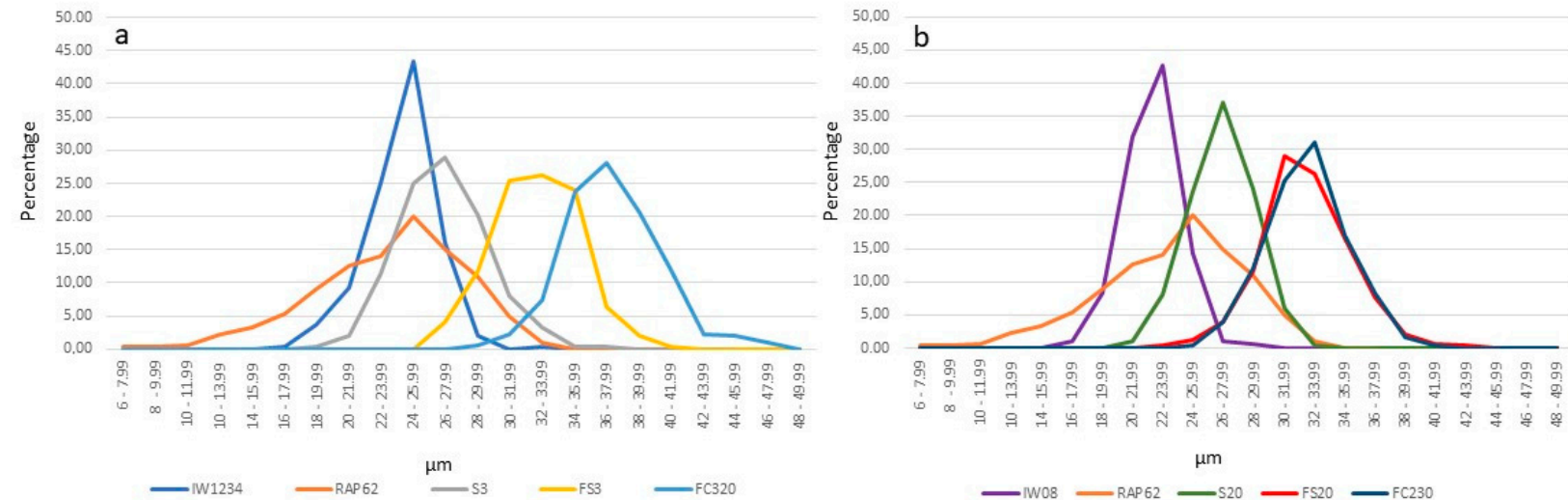

Figure 7. Distribution of stomata length in percentage in parental genotypes and interspecific hybrids. (a) Head cabbage IW1234, rapeseed RAP62, S3F1 (head cabbage IW1234 × rapeseed RAP62), FS3 F2 (S3 $\times$ self), and FS320 F2 (S3 $\times$ mixture of pollen). (b) Kale IW08, rapeseed RAP62, S20 F1 (IW08 kale $\times$ RAP62 rapeseed), FS20 (S20 $\times$ self), and FS230 F2 $($ S20 $\times$ mixture of pollen).

\section{Discussion}

In the genus Brassica, hexaploid species do not exist in nature, as tetraploidy $(4 \mathrm{x})$ is the highest naturally occurring ploidy [36]. There are different approaches to hexaploid induction. Trigenomic hexaploids (AABBCC) with 54 chromosomes were produced in Brassica through interspecific hybridisation of B. napus (AACC genome) and B. nigra (BB genome), followed by colchicine treatment [36]. In a similar manner, trigenomic hexaploids (AABBCC) were obtained from B. campestris sp. chinensis (AA) and B. carinata (BBCC) crosses after artificial chromosome doubling of $F_{1}$ hybrids [37]. Treatment of triploid ACC hybrids with colchicine led to hexaploid AACCCC genotype development; these hybrids were 
largely used as bridge plants for the introgression of genomic components of $B$. rapa into B. napus [38]. Mason et al. [39] showed the possibility of producing trigenomic allohexaploid Brassica through unreduced gametes. The allohexaploid (6x) and aneuploid AACCCC Brassica hybrids analysed in this study were created by interploid crosses between diploids of kale (CC) and head cabbage (CC), with tetraploid B. napus (AACC), followed by selfpollination and open-cross-pollination of triploid $F_{1}$ hybrids (ACC). These results indicate that ploidy manipulation in Brassica is possible via euploid gametes produced by hybrids. The distribution of pollen sizes showed great variation in grain sizes, both in $\mathrm{S}_{3} \mathrm{~F}_{1}$ (head cabbage $\times$ rapeseed) and $\mathrm{S}_{2} \mathrm{~F}_{1}$ (head cabbage $\times$ rapeseed) hybrids (Figures $4 \mathrm{e}, 5$ and $\mathrm{S} 1 \mathrm{q}, \mathrm{r}$ ). There was considerable evidence in the literature that in Brassica, interspecific triploid hybrids can produce euploid $(x, 2 x, 3 x)$ and aneuploid gametes [22,40-42], and the success in ploidy manipulation depends on the lines selected for hybridisation. According to He et al. [43], due to abnormal meiotic processes and cytogenetic instability, aneuploids can be expected when using triploids or tetraploids in crosses with other genotypes, regardless of their ploidy levels. Li et al. [22] reported a high frequency of allotetraploid-like gametes in the interspecific hybrids between B. napus and B. oleracea.

The total nuclear DNA content per cell significantly influenced the phenotypic traits (nucleotypic effects). Cell size, pollen grain diameter, stomata length, and stomatal plastid number are positively correlated with genome size, and they are often used as morphological markers for identifying the ploidy level of plants [44-46]. Furthermore, seed size, stomatal density, and pollen fertility are usually related to the ploidy level [46]. For instance, a positive relationship was found between the ploidy level and stomatal guard cell length and width, and a negative correlation was observed between ploidy level and stomatal density for diploid and triploid Citrus clementina [47] and stomata length and pollen size in diploid and tetraploid tulips [31] and apples [48]. In Brassica, a high correlation between ploidy and stomata lengths was reported for trigenomic hexaploid hybrids (AABBCC) [36]. Similarly, in our study, both stomata length and pollen grain diameters were significantly higher as ploidy increases, whereas the density of stomata on the abaxial epidermis decreased. The number and distribution of stomata per unit leaf area may have consequential roles in moisture exchange between the leaves and atmosphere [49]. According to Padoan et al. [47], leaf water loss is higher in diploid plants than in triploids, which are characterised by decreased stomatal density. Thus, the size and stomatal density influence the adaptation to various environmental conditions and productivity of the plants.

The doubling of the cell genome usually leads to increased organ size. In our study, the vegetative and reproductive organs of hexaploids were larger than those of the diploid and tetraploid parents and triploid $\mathrm{F}_{1}$ hybrids (Figure 4, Figure S1 and S2). Larger vegetative and reproductive organs were also observed in hexaploids derived from $B$. rapa and B. carinata [50]. Trigenomic hexaploid Brassica hybrids (AABBCC) derived from B. napus L. and $B$. nigra were more vigorous, had broader and thicker leaves, and the hairs on leaves and stems were more abundant compared to triploid $(\mathrm{ABC})$ hybrids and their parents [36]. Some of the changes observed in polyploids are of high agronomical value. Plants of the $\mathrm{F}_{2}$ generation had bigger and thicker leaves and significantly thicker layers of palisade and spongy mesophyll than triploids of the $F_{1}$ generation and parental lines of $B$. oleracea and B. napus, whereas FC320 $F_{2}$ had a compact mesophyll structure with small intercellular spaces. The leaf surface and leaf morphological characteristics may affect their resistance to infestation by insect herbivores [51-53]. Marasek-Ciolakowska et al. [53] showed that reduced infestation by the cabbage whitefly (Aleyrodes proletella) on leaves of resistant cultivars of kale and savoy cabbage was related to the structure of the epidermis, thickness of the lamina, and compactness of the mesophyll.

The morphological appearance of flowers in $\mathrm{F}_{1}$ (ACC) and $\mathrm{F}_{2}$ (AACCCC) hybrids was similar to $B$. napus, except that the organs were larger. Hexaploids had significantly larger flower buds, flowers, and anthers compared to triploids. Larger flowers, petals, and stamens were also observed in hexaploid Brassica (AABBCC) hybrids derived from a colchicine treatment of triploid $(\mathrm{ABC})$ hybrids of $B$. napus (AACC) $\times$ B. nigra (BB) [36] 
and B. carinata $(\mathrm{BBCC}) \times$ B. rapa $(\mathrm{AA})$ [54]. Flowers and flower elements of $4 \times$ plants of B. rapa were larger than diploid and haploid plants [55]. We observed a negative effect of polyploidy on the length of pods and seed set of the allopolyploid hybrids when compared to diploid and tetraploid progenitors. However, pod length and seed number per pod in the hexaploid plants increased significantly compared to triploids, and seeds were produced without embryo rescue. The ability for seed development was better after open pollination compared to self-pollination of $F_{1}$ hybrids. Similarly, the seed development in plants of $\mathrm{F}_{1} \times \mathrm{F}_{2}$ and $\mathrm{BC}_{1} \times \mathrm{F}_{1} / \mathrm{F}_{2}$ generations of $\mathrm{B}$. oleracea $\times$ B. napus after pollination by the mixture of pollen was higher than that of $\mathrm{F}_{1}$ and $\mathrm{BC}_{1}$ (B. oleracea) generations [30].

Another feature of agronomic importance is the size of nectaries. Nectaries secrete floral nectar, which attracts flower pollinators. Flowers of Brassica spp. have two pairs, which differ in structure and location [55]. Lateral nectaries are found above the base of shorter stamens, whereas median nectaries are located external to the base of the long stamen. In our study, the lateral nectaries of hexaploid plants were significantly larger than their triploid $F_{1}$ progenitors (Table 2, Figure S1). This characteristic suggests that flowers of allohexaploid Brassica hybrids may be more attractive to pollinators.

Our observations agree with previous studies showing that the Brassica genome is characterised by high plasticity with respect to the level of ploidy. Besides the described triploids, tetraploids, and hexaploids, there are also successful examples of octoploid formation with a significantly changed appearance $[11,56]$. For example, autoallooctoploids $B$. napus (AAAACCCC; $2 n=8 x=76$ ) were obtained by doubling the genome of allotetraploid B. napus. Compared to tetraploids, octoploid B. napus showed significant differences in phenotype, such as decreased vegetative organ size, increased number of pollen apertures, moderate reproductive ability, high pollen variability, and a relatively stable meiotic process [11].

In our study, we confirmed that meiotic polyploidisation can be a promising method to obtain new germplasm showing the traits of both B. napus and B. oleracea that can be used as initial material for the development of new types of leafy vegetables.

\section{Conclusions}

Allohexaploid AACCCC Brassica hybrids of the $\mathrm{F}_{2}$ generation were created by crossing diploid kale and head cabbage with tetraploid B. napus, followed by self-pollination. A positive correlation between genome size and chromosome number was found in $F_{1}$ and $F_{2}$ interspecific hybrids of $B$. oleracea $\times B$. napus. Allohexaploid $F_{2}$ hybrids showed abundant phenotypic and anatomical variations, including larger and thicker leaves and larger flowers than the diploid and tetraploid parents and triploid $F_{1}$ hybrids. Stomata size was generally positively correlated with ploidy level. Interspecific hybrids of the $F_{2}$ generation derived by open crosses between plants of the $F_{1}$ generation (FC320, FC230) had a good seed set ability. Moreover, a comparative anatomical analysis showed that leaves of FC320 $\mathrm{F}_{2}$ hybrids were characterised by a thicker and more compact mesophyll structure than other genotypes.

All $F_{2}$ hybrids were also male fertile, and pollen fertility of the $F_{2}$ population was significantly increased compared to F1 hybrids and even reached normal levels of the diploid and tetraploid parents. Analysed hybrids can be used for breeding Brassica at the hexaploid level, potentially leading to the development of new polyploid leafy vegetables.

Supplementary Materials: The following supporting information can be downloaded at: https:/ / www.mdpi.com/article/10.3390/agronomy12010026/s1, Figure S1: Phenotypic characteristic of flowers and pollen viability of parental genotypes and the interspecific hybrids of B. oleracea $\times$ B. napus of the $F_{1}$ and $F_{2}$ generations; Figure S2: Morphological and anatomical characteristics of leaves and flower stacks.

Author Contributions: Conceptualization, A.M.-C. and P.K.; funding acquisition, P.K., A.M.-C. and M.S.; investigation, A.M.-C., P.K., M.S., M.P., U.K. and E.S.-K.; methodology, A.M.-C., P.K., M.P., M.S., U.K. and E.S.-K.; project administration, A.M.-C.; resources, M.S., E.S.-K. and U.K.; supervision, 
A.M.-C.; writing-original draft, A.M.-C. and P.K.; writing-review and editing, A.M.-C., P.K. and M.P. All authors have read and agreed to the published version of the manuscript.

Funding: The study was funded by the Polish Ministry of Science and Higher Education through statutory funds (ZBS/7/2021) of The National Institute of Horticultural Research, Skierniewice, Poland.

Institutional Review Board Statement: Not applicable.

Informed Consent Statement: Not applicable.

Data Availability Statement: Not applicable.

Conflicts of Interest: The authors declare no conflict of interest.

\section{References}

1. Masterson, J. Stomatal size in fossil plants: Evidence for polyploidy in majority of Angiosperms. Science 1994, 264, 421-424. [CrossRef]

2. Casacuberta, J.M.; Jackson, S.; Panaud, O.; Purugganan, M.; Wendel, J. Evolution of plant phenotypes, from genomes to traits. G3 Genes Genomes Genet. 2016, 6, 775-778. [CrossRef]

3. Sattler, M.C.; Carvalho, C.R.; Clarindo, W.R. The ploidy and its key role in plant breeding. Planta 2016, 243, 281-296. [CrossRef]

4. Marasek-Ciolakowska, A.; Sochacki, D.; Marciniak, P. Breeding aspects of selected ornamental bulbous crops. Agronomy 2021, 11, 1709. [CrossRef]

5. Kreiner, J.M.; Kron, P.; Husband, B.C. Frequency and maintenance of unreduced gametes in natural plant populations: Associations with reproductive mode, life history and genome size. New Phytol. 2017, 214, 879-889. [CrossRef]

6. Ramsey, J.; Schemske, D.W. Pathways, mechanisms, and rates of polyploid formation in flowering plants. Annu. Rev. Ecol. Syst. 1998, 29, 467-501. [CrossRef]

7. Pecinka, A.; Fang, W.; Rehmsmeier, M.; Levy, A.A.; Scheid, O.M. Polyploidization increases meiotic recombination frequency in Arabidopsis. BMC Biol. 2011, 9, 24. [CrossRef] [PubMed]

8. Dar, J.A.; Beigh, Z.A.; Wani, A.A. Polyploidy: Evolution and crop improvement. In Chromosome Structure and Aberration; Chapter 10; Bhat, T.A., Wani, A.A., Eds.; Springer: New Delhi, India, 2017; pp. 201-217.

9. Podwyszyńska, M.; Marasek-Ciolakowska, A. Ploidy, Genome Size, and Cytogenetics of Apple. In The Apple Genome, Compendium of Plant Genomes; Korban, S.S., Ed.; Springer: Cham, Switzerland, 2021. [CrossRef]

10. Lage, J.; Trethowan, R.M. CIMMYT's use of synthetic hexaploid wheat in breeding for adaptation to rainfed environments globally. Aus. J. Agri. Res. 2008, 59, 461-469. [CrossRef]

11. Yin, L.; Zhu, Z.; Luo, X.; Huang, L.; Li, Y.; Mason, A.S.; Yang, J.; Ge, X.; Long, Y.; Wang, J.; et al. Genome-Wide duplication of allotetraploid Brassica napus produces novel characteristics and extensive ploidy variation in self-pollinated progeny. G3 Genes Genomes Genet. 2020, 10, 3687-3699. [CrossRef]

12. Cheng, F.; Wu, J.; Wang, X. Genome triplication drove the diversification of Brassica plants. Hortic. Res. 2014, 1, 14024. [CrossRef]

13. Katche, E.; Quezada-Martinez, D.; Katche, E.I.; Vasquez-Teuber, P.; Mason, A.S. Interspecific hybridization for Brassica crop improvement. Crop Breed. Genet. Genom. 2019, 1, e190007. [CrossRef]

14. Nagaharu, U. Genome analysis in Brassica with special reference to the experimental formation of Brassica napus and peculiar mode of fertilization. Jap. J. Bot. 1935, 7, 389-453.

15. Chalhoub, B.; Denoeud, F.; Liu, S.; Parkin, I.A.; Tang, H.; Wang, X.; Chiquet, J.; Belcram, H.; Tong, C.; Samans, B.; et al. Early allopolyploid evolution in the post-Neolithic Brassica napus oilseed genome. Science 2014, 345, 950-953. [CrossRef]

16. Roy, N.N. Interspecific tranfer of Brassica juncea-type high blackleg resistance to Brassica napus. Euphytica 1984, 33, 295-303. [CrossRef]

17. Gerdemann-Knorck, M.; Nielen, S.; Tzscheetzsch, C.; Iglisch, J.; Schieder, O. Transfer of disease resistance within the genus Brassica through asymmetric somatic hybridization. Euphytica 1995, 85, 247-253. [CrossRef]

18. Sharma, B.B.; Kalia, P.; Singh, D.; Sharma, T.R. Introgression of Black Rot Resistance from Brassica carinata to Cauliflower (Brassica oleracea botrytis Group) through Embryo Rescue. Front. Plant Sci. 2017, 8, 1255. [CrossRef]

19. Tonguc, M.; Griffiths, P.D. Transfer of powdery mildew resistance from Brassica carinata to Brassica oleracea through embryo rescue. Plant Breed. 2008, 123, 587-589. [CrossRef]

20. Mafakheri, M.; Kordrostami, M. Biotechnological Approach for Enhancing Capability of Brassica oleracea var. italica Against Stresses Under Changing Climate. In The Plant Family Brassicaceae; Hasanuzzaman, M., Ed.; Springer: Singapore, 2020. [CrossRef]

21. Seepaul, R.; Kumar, S.; Iboyi, J.E.; Bashyal, M.; Stansly, T.L.; Bennett, R.; Boote, K.J.; Mulvaney, M.J.; Small, I.M.; George, S.; et al. Brassica carinata: Biology and agronomy as a biofuel crop. GCB Bioenergy 2021, 13, 582-599. [CrossRef]

22. Li, Z.; Wang, Y. Cytogenetics and germplasm enrichment in Brassica allopolyploids in China. J. Integr. Agric. 2017, 16, 2698-2708. [CrossRef]

23. Wang, G.-X.; Tang, Y.; Yan, H.; Sheng, X.-G.; Hao, W.-W.; Zhang, L.; Lu, K.; Liu, F. Production and characterization of interspecific somatic hybrids between Brassica oleracea var. botrytis and B. nigra and their progenies for the selection of advanced pre-breeding materials. Plant Cell Rep. 2011, 30, 1811-1821. [CrossRef] 
24. Gaebelein, R.; Alnajar, D.; Koopmann, B.; Mason, A.S. Hybrids between Brassica napus and B. nigra show frequent pairing between the B and A/C genomes and resistance to blackleg. Chromosome Res. 2019, 27, 221-236. [CrossRef]

25. Wei, Y.; Zhu, M.; Qiao, H.; Li, F.; Zhang, S.; Zhang, S.; Zhang, H. Characterization of interspecific hybrid between flowering Chinese cabbage and broccoli. Scientia Hortic. 2018, 240, 552-557. [CrossRef]

26. Lee, S.S.; Lee, S.A.; Yang, J.; Kim, J. Developing stable progenies of $\times$ Brassicoraphanus, an intergeneric allopolyploid between Brassica rapa and Raphanus sativus, through induced mutation using microspore culture. Theor. Appl. Genet. 2011, 122, 885-891. [CrossRef]

27. Dixon, G.R. Vegetable Brassicas and Related Crucifers; CAB International: Wallingford, UK, 2007; 327p.

28. Starzycki, M.; Starzycka, E.; Pszczoła, J. Development of Alloplasmic Rape. Adv. Bot. Res. 2007, 45, $313-335$.

29. Kamiński, P.; Podwyszyńska, M.; Starzycki, M.; Starzycka-Korbas, E. Interspecific hybridisation of cytoplasmic male-sterile rapeseed with Ogura cytoplasm and Brassica rapa var. pekinensis as a method to obtain male-sterile Chinese cabbage inbred lines. Euphytica 2016, 208, 519-534. [CrossRef]

30. Kamiński, P.; Marasek-Ciolakowska, A.; Podwyszyńska, M.; Starzycki, M.; Starszycka-Korbas, E.; Nowak, K. Development and characteristics of interspecific hybrids between Brassica oleracea L. and B. napus L. Agronomy 2020, 10, 1339. [CrossRef]

31. Podwyszyńska, M.; Trzewik, A.; Marasek-Ciołakowska, A. In vitro polyploidisation of tulips (Tulipa gesneriana L.)—Phenotype assessment of tetraploids. Sci. Hortic. 2018, 242, 155-163. [CrossRef]

32. Marasek-Ciolakowska, A.; He, H.; Bijman, P.; Ramanna, M.S.; Arens, P.; van Tuyl, J.M. Assessment of intergenomic recombination through GISH analysis of F1, BC1 and BC2 progenies of Tulipa gesneriana and T. fosteriana. Plant Syst. Evol. 2012, 298, 887-899. [CrossRef]

33. Alexander, M.P. Differential staining of aborted and nonaborted pollen. Stain. Technol. 1969, 44, 117-122. [CrossRef]

34. Marasek-Ciolakowska, A.; Saniewski, M.; Dziurka, M.; Kowalska, U.; Góraj-Koniarska, J.; Ueda, J.; Miyamota, K. Formation of the secondary abscission zone Induced by the interaction of methyl jasmonate and auxin in Bryophyllum calycinum: Relevance to auxin status and histology. Int. J. Mol. Sci. 2020, 21, 2784. [CrossRef] [PubMed]

35. Dyki, B.; Habdas, H. Metoda izolowania epidermy liści pomidora i ogórka dla mikroskopowej oceny rozwoju grzybów patogenicznych. (The method of isolation of epidermis of tomato and cucumber leaves for microscopic investigation of pathogenic fungus development). Acta Agrobot. 1996, 49, 123-129. (In Polish) [CrossRef]

36. Pradhan, A.; Plummer, J.A.; Neslon, M.N.; Cowling, W.A.; Yan, G. Successful induction of trigenomic hexaploid Brassica from a triploid hybrid of B. napus L. and B. nigra (L.) Koch. Euphytica 2010, 176, 87-98. [CrossRef]

37. Meng, J.L.; Shi, S.; Li, G.; Li, Z.; Qu, X. The production of yellow-seeded Brassica napus (AACC) through crossing interspecific hybrids of B. campestris (AA) and B. carianata (BBCC) with B. napus. Euphytica 1998, 103, 329-333. [CrossRef]

38. Zhang, K.; Mason, A.S.; Fariiq, M.A.; Islam, F.; Quezada-Martinez, D.; Hu, D.; Yang, S.; Zou, J.; Zhou, W. Challenges and prospects for a potential allohexaploid Brassica crop. Theor. App. Genet. 2021, 134, 2711-2726. [CrossRef] [PubMed]

39. Mason, A.S.; Yan, G.; Cowling, W.A.; Nelson, M.N. A new method for producing allohexaploid Brassica through unreduced gametes. Euphytica 2012, 186, 277-287. [CrossRef]

40. Silkova, O.G.; Shchapova, A.I.; Shumny, V.K. Patterns of meiosis in ABDR amphihaploids depend on the specific type of univalent chromosome division. Euphytica 2011, 178, 415-426. [CrossRef]

41. Xiong, Z.Y.; Gaeta, R.T.; Pires, J.C. Homoeologous shufing and chromosome compensation maintain genome balance in resynthesized allopolyploid Brassica napus. Proc. Natl. Acad. Sci. USA 2011, 108, 7908-7913. [CrossRef]

42. Bhatia, R.; Sharma, K.; Parkash, C.; Pramanik, A.; Singh, D.; Singh, S.; Kumar, R.; Dey, S.S. Microspore derived population developed from an inter-specific hybrid (Brassica oleracea $\times$ B. carinata) through a modifed protocol provides insight into B genome derived black rot resistance and inter-genomic interaction. Plant Cell Tissue Organ Cult. (PCTOC) 2021, 145, 417-434. [CrossRef]

43. He, D.; Jing, J.; Snowdon, R.J.; Mason, A.S.; Shen, J.; Meng, J.; Zou, J. Exploring the gene pool of Brassica napus by genomics-based approaches. Plant Biotech. J. 2021, 19, 1693-1712.

44. Yuan, S.-x.; Liu, Y.-m.; Fang, Z.-y.; Yang, L.-m.; Zhuang, M.; Zhang, Y.-y.; Sun, P.-t. Study on the relationship between the ploidy level of microspore-derived plants and the number of chloroplasts in stomatal guard cells in Brassica oleracea. Agr. Sci. China 2009, 8, 939-946. [CrossRef]

45. Sohn, S.-I.; Oh, Y.-J.; Lee, K.-R.; Ko, H.-C.; Cho, H.-S.; Lee, Y.-H.; Chang, A. Characteristics analysis of F1 hybrids between genetically modified Brassica napus and B. rapa. PLoS ONE 2016, 11, e0162103. [CrossRef] [PubMed]

46. Dewitte, A.; Van Laere, K.; Van Huylenbroeck, J. Use of 2n gametes in plant breeding. In Plant Breeding; Abdurakhmonov, I.Y., Ed.; Intech.: Rijeka, Croatia, 2011; pp. 59-86.

47. Padoan, D.; Mossad, A.; Chiancone, B.; Germana, M.A.; Kjan, P.S.S.V. Ploidy levels in Citrus clementine affects leaf morphology, stomatal density and water content. Theor. Exp. Plant. Physiol. 2013, 25, 283-290. [CrossRef]

48. Podwyszyńska, M.; Markiewicz, M.; Broniarek-Niemiec, A.; Matysiak, B.; Marasek-Ciolakowska, A. Apple autotetraploids with enhanced resistance to apple scab (Venturia inaequalis) due to genome duplication-phenotypic and genetic evaluation. Int. J. Mol. Sci. 2021, 22, 527. [CrossRef]

49. Brownlee, C. The long and short of stomata density signals. Trends Plant Sci. 2001, 6, 441-442. [CrossRef]

50. Li, M.; Qian, W.; Meng, J.; Li, Z. Construction of novel Brassica napus genotypes through chromosomal substitution and elimination using interploid species hybridization. Chromosome Res. 2004, 12, 417-426. [CrossRef] 
51. Seki, K. Leaf-morphology-assisted selection for resistance to two-spotted spider mite Tetranychus uriticae Koch (Acari: Tetranychidae) in carnations (Dianthus caryophyllus L.). Pest Manag. Sci. 2016, 72, 1926-1933. [CrossRef]

52. Goiana, E.S.S.; Dias-Pini, N.S.; Muniz, C.R.; Soares, A.A.; Alves, J.C.; Vidal-Neto, F.C.; Da Silva, C.S.B. Dwarf-cashew resistance to whitefly (Aleurodicus cocois) linked to morphological and histochemical characteristics of leaves. Pest Manag. Sci. 2020, 76, 464-471. [CrossRef] [PubMed]

53. Marasek-Ciolakowska, A.; Soika, G.; Warabieda, W.; Kowalska, U.; Rybczyński, D. Investigation on the relationship between morphological and anatomical characteristic of savoy cabbage and kale leaves and infestation by cabbage whitefly (Aleyrodes proletella L.). Agronomy 2021, 11, 275. [CrossRef]

54. Malek, M.A.; Rahman, L.; Das, M.L.; Hassan, L.; Rafii, M.Y.; Ismail, M.R. Development of hexaploid Brassica (AABBCC) from hybrids $(\mathrm{ABC})$ of Brassica carinata $(\mathrm{BBCC}) \times$ B. rapa (AA). Aust. J. Crop Sci. 2013, 7, 1375-1382.

55. Davis, A.R.; Fowke, L.C.; Sawhney, V.K.; Low, N.H. Floral nectar secretion and ploidy in Brassica rapa and B. napus (Brassicaceae). II. Quantified variability of nectary structure and function in rapid-cycling lines. Ann. Bot. 1996, 77, 223-234. [CrossRef]

56. Liu, S.; Liu, Y.; Yang, X.; Tong, C.; Edwards, D.; Parkin, I.A.; Zhao, M.; Ma, J.; Yu, J.; Huang, S.; et al. The Brassica oleracea genome reveals the asymmetrical evolution of polyploid genomes. Nat. Commun. 2014, 5, 3930. [CrossRef] [PubMed] 